\title{
Editorial
}

\section{Publish and flourish: seasonal advice to our readers}

The editors of a scientific journal should not be expected to police the activities of their less law-abiding colleagues. Nonetheless, situations arise in which this becomes necessary, and they are unsavoury for all involved, not least the editors themselves. As the season of goodwill towards all men (and women), editors and authors alike, approaches, we felt it timely to discuss one issue which has forced us on occasion to lay down the law. The problem is abundance (an appropriate word for the more fortunate amongst us as the end of the year approaches) and the redundancy it creates in the scientific literature. Consider two examples. First, the ever increasing number of journals. The much abused, but on occasion valid, spectre of Impact Factors is injuring our less competitive brethren, but this will probably not prevent the relentless increase in their number. The situation will degenerate further with the advent of the electronic age. It is thus to be feared that the "information super-highway", which is already inundated with third-rate gossip (and worse), will become further encumbered by third-rate science. The second example is redundant publication of scientific studies, the focus of this editorial. The two are of course related: the more thirdrate journals, the easier it is to publish redundant data.

In keeping with the seasonal spirit, let us tackle this chestnut together. Ultimately, the authors of articles appearing in these pages must be held responsible for their scientific integrity. We as editors can only serve as (we admit occasionally misguided) guides and as will become apparent from this editorial, we can offer no list of golden rules in this particular context. The purpose of this editorial is merely to highlight the dilemma we must face together.

\section{To slice or not to slice}

The noxious practice of dividing scientific studies into a needless number of overlapping reports is often called "salami slicing". This is an affront to a delicious Italian speciality! What is more, a salami should be sliced before it is eaten; a scientific study should not be sliced before it is published! Leaving semantics and etiquette aside, the concept of redundant publications will be all too familiar to you, our readers. We certainly hope that this will not come from reading Diabetologia or from perusing your own written works over the years. The problem is a universal one, discussed in some depth in a recent editorial in the New England Journal of Medicine [1], illustrated by examples from the editor's files. We could, alas, do the same - but this is not the season for witchhunting. Rather, let us consider two random, but certainly representative theoretical cases (any resemblance to real life is of course intentional).

The case of the versatile patient group: the "squeeze the most out of your samples and then squeeze some more" syndrome

Whenever possible, all data from a given patient group should be gathered together in a single publication. Splitting related data into different papers is thus not acceptable. The situation is not, alas, so simple. Consider first an absurd extreme. Accumulating vitally important data over 20 years and publishing a single 1000 page "article" just to satisfy these criteria would clearly be idiotic and scientifically irresponsible. Other situations, however, demand less straightforward "fine line" decisions, as illustrated by the following example. A patient group was studied for syndrome "A", and serum levels of $A_{1}, A_{2}, A_{n}$ were measured. The study was published. Two months later, the same authors measure serum levels of $B_{1}, B_{2}, B_{n}$ 
and they submit a paper describing syndrome " $\mathrm{B}$ " in their patient group (same authors, same patients, same serum samples, different assays, different syndrome). In a separate manuscript to another journal they correlate levels of $\mathrm{A}$ and $\mathrm{B}$ with diabetes. And so the saga could continue, starting with the perfectly legitimate publication of an original study and ending at the opposite extreme, with a large number of redundant papers. Deciding where to draw the line separating the acceptable from the unacceptable is not always easy. What is more, those who "slice" will certainly not follow the instructions to authors by sending "related" material to the editor (i.e. papers in press or submitted elsewhere) since they will reason that such material was not in fact related at all to the manuscript in question.

The case of the overcloned gene: the "if rat and man have it, so must goldfish and rhinoceros" syndrome

More recent problems in redundant publication have arisen as a direct consequence of modern molecular biology technology. Diabetologia, in common with most journals, has not escaped the attention of the less scrupulous representatives of the "gene jockey" community over the past few years. The case of the overcloned gene provides an excellent example. A cDNA encoding your favourite protein has been cloned in the rat and the sequence has been published. Dr. Clonitis now rapidly clones and sequences a human cDNA encoding the same protein, and submits a paper to Diabetologia. The paper may well be rejected, unless the human sequence is accompanied by new insight into the function of the protein in question. The next two papers from Dr. Clonitis reporting the sequence of the goldfish and rhinoceros cDNAs will certainly be rejected. There are appropriate journals for publishing nucleic acid sequences and protein evolutionary trees; Diabetologia is not one. Imagine, however, that aside from cloning the human cDNA you (Dr. Clonitis rarely if ever extends his studies to issues of potential biological or clinical relevance) have now measured mRNA levels for the gene in question in various tissues and shown them to be elevated in NIDDM. This would clearly constitute an original contribution to the field and would be welcome as a paper in Diabetologia. But what if the mRNA levels were not altered in diabetes? This would now be a paper with the sequence of a human cDNA (rat already published) with negative data for a functional role of the corresponding protein in diabetes. The quality of the work, the integrity of the scientists and indeed the importance of the observation would not be in question, but you must admit that the editorial decision now becomes harder. Was it logical to expect this gene to be implicated in diabetic? Did the authors measure mRNA levels in the right tissues? Is there a mutation in the gene in diabe- tic patients (the authors only measured mRNA levels)? Are there regulatory proteins? We leave you to complete the list (and similar reasoning can be applied to population genetics). Just as for our first example with the patient group, the line dividing true scientific interest and redundancy is fine and often fuzzy.

\section{Warning: slicing it too thin has been shown to be hazardous to your career}

Why do scientists "slice" in the first place? The reasons are all too obvious and we do not propose to bore you with a long list of depressing human traits in this season of hope and joy! Our only message must be that the perpetrator will suffer sooner or later (and usually sooner). The author of redundant papers at first swells his bibliography to grand effect, possibly attracting the eye of search committees and the local newspaper (if anyone bothered to look, they would surely discover a direct correlation between self-advertisement in the written press and on television shows, and redundant publication in scientific journals), only to find himself treated as an outcast by his peers and perhaps even jobless. Alas, it is common knowledge that this irreversible progression from star to pariah is the inevitable fate of all colleagues who have played this particularly destructive game, leading them to the sorry situation of having perished as a direct consequence of their multiple publications. What is worse, we, as readers, suffer as well. Redundancy in the scientific literature is intrinsically counterproductive. At best, it wastes time, paper and money. At worst, it has a real influence on the impact of the work in question, more often than not affording it unwarranted extra attention to the detriment of more worthy related (and unrelated, given the constraints on space in the better journals such as Diabetologia) studies.

\section{Publish and flourish or publish and perish?}

In closing, here are a couple of suggestions (but not rules or regulations) to help us all flourish as we publish.

1. Read what you sign: Diabetologia, in common with most other journals [1] asks for copies of related manuscripts and authors must sign a statement attesting to the originality of their work. Our first suggestion is to read the statement before signing! In particular, note that in signing one is stating to the editor (and future readers) that "neither the manuscript submitted nor any part of it has been published or is being considered for publication elsewhere in any language or any form" (citation from current Dia- 
betologia instructions to authors). Deciding whether published papers or manuscripts under consideration elsewhere do in fact overlap with the work you are about to submit should not be that difficult. If in doubt, send the potentially offending items to the editor so that he can help you decide.

2. A little good sense can go a long way. Even with research funding as tight as it now is in all countries, and job prospects as bleak as ever, submit a paper as you were (hopefully) taught as a child to cross the road. "Stop, look left then right (depending upon where you live in the world), look left again, then submit". To your left, imagine members of your family and your closest friends. To the right, those scientists you most admire. Is your paper up to their standard? Do you wish them to recognise you by this study? The an- swers should be affirmative and unequivocal. If they are not, you cannot afford to ignore them. Certainly neither the editors of a scientific journal nor its readers can help you ask or answer these questions. However, they can usually tell when you have failed to do so. But by then it is too late. The rabbit is out of the hat, and your good reputation is disappearing fast with the rabbit!

\section{References}

1. Kassirer IP, Angell M (1995) Redundant publication: a reminder. New Engl J Med 333: 449-450

Philippe Halban

Deputy Editor

1 December 1995 